\title{
A Debreceni Egyetem Gazdaságtudományi Karának Controlling és teljesítménymenedzsment szakirány kurzusainak értékelése
}

\author{
V Markos ${ }^{1}$, A. D. Tóth ${ }^{2}$, I Kocsis ${ }^{3}$, E MÁthé $^{4}$, Cs JuHÁSz $^{5}$, É BÁCsné BÁBA ${ }^{6}$, V FenYVES $^{7}$ \\ ${ }^{1}$ Debreceni Egyetem, Bölcsésztudományi Kar, markos.valeria@arts.unideb.hu \\ 2Debreceni Egyetem, Bölcsésztudományi Kar, markos.valeria@arts.unideb.hu \\ ${ }^{3}$ Debreceni Egyetem, Műszaki Kar, kocsisi@eng.unideb.hu \\ ${ }^{4}$ Debreceni Egyetem, Mezőgazdaság-, Élelmiszertudományi és Környezetgazdálkodási Kar, mathe@agr.unideb.hu \\ ${ }^{5}$ Debreceni Egyetem, Mezőgazdaság-, Élelmiszertudományi és Környezetgazdálkodási Kar, juhasz@agr.unideb.hu \\ 6Debreceni Egyetem, Gazdaságtudományi Kar, bacsne.baba.eva@econ.unideb.hu \\ 7Debreceni Egyetem, Gazdaságtudományi Kar, fenyves.veronika@econ.unideb.hu
}

\begin{abstract}
Absztrakt. A Debreceni Egyetem Gazdaságtudományi Kara számára kiemelten fontos, hogy megismerje a hallgatók egyetemen folyó képzéssel kapcsolatban megfogalmazott véleményét, ezért nagy figyelmet fordít az oktatás hallgatói véleményezésére. A mérés és az értékelés több célt is szolgál. A hallgatók - amennyiben az oktató ehhez írásban, kifejezetten hozzájárul - megismerhetik hallgatótársaiknak az egyes kurzusokról kialakult véleményét, az oktatók visszajelzést kapnak kurzusuk megítélésrôl, az Egyetem és a Karok pedig információhoz jutnak arról, hogy hallgatóik milyen véleményt alkottak a képzésrôl. A visszajelzések összességében alkalmasak a képzés minőségének fejlesztésére irányuló munka támogatására. Jelen tanulmány keretében a Vezetés és Szervezés Szak Controlling és teljesítménymenedzsment szakirány hallgatói által leadott értékeléseket mutatjuk be.
\end{abstract}

Abstract. It is of major importance for the Faculty of Economics and Business of the University of Debrecen to become familiar with the opinion of students about the education carried out at the University, therefore particular attention is given to the feedback of students related to education. Measurement and evaluation/reviews serve multiple purposes. Students may - if explicit written consent of the lecturer is provided - get to know the opinion of their fellow students about each course, lecturers may receive feedback about the reputation of their courses, the University and Faculties may acquire information about the overall opinion of their students about the training. Feedback is basically suitable for supporting the work aimed at the improvement of training quality. In the scope of present study the reviews submitted by the students of the Controlling and performance specialisation within the Management and Organisation course are introduced.

\section{Bevezetés}

A tanítás-tanulás rendszerszemléletében azt nevezzük értékelésnek, amikor a tanulás-tanítás eredményei és a tanítás célja között összefüggéseket keresünk [1]. Értékelés nélkül pedig nem elképzelhető a pedagógiai folyamat. A felsőoktatásban vannak olyan elemek (a közoktatásban meglévő 
elemeken túl), amikkel számolnunk kell az értékelés során, ilyen elemek a hallgatók tudásának megfelelése a követelményeknek, a megfelelő információátadás, az oktatás céljainak megválasztása, a célokhoz illeszkedő követelményrendszer felállítása, az egyetem által elvárt minőségi szinthez való igazodás és a tanulmányi és vizsgaszabályzat törvényessége. Az értékelés tervezésekor fontos meghatároznunk a visszacsatolás idejét és gyakoriságát, ez a felsőoktatásban általában egy fél évet ölel fel, hiszen egy félév alatt nyilvánvalóvá válnak a kurzus teljesítésének problémái, a tananyag elsajátításának nehézségei [2]. Jelen tanulmányunk célja az, hogy a Debreceni Egyetem Gazdaságtudományi Kar (DE-GTK) Kontrolling szakirányhoz tartozó kurzusokat az oktatói tevékenységről készített a hallgatói értékeléseket bemutassuk. A hallgatók részéről történő értékelés során visszajelzést kapnak az oktatók a munkájuk megítéléséről, továbbá elősegíti az egyéni fejlődés megalapozását is. Nemcsak az oktatók „profitálnak” a hallgatói véleményekből, hanem a DE-GTK vezetősége is, hiszen képet kapnak az értékelésekből az oktatói követelményrendszer teljesíthetőségéről is.

\section{A felsőoktatás-pedagógia}

Felmerülhet a kérdés, hogy tanár-e az egyetemi oktató. Ha megvizsgáljuk azt, hogy milyen kompetenciákkal kell rendelkeznie egy oktatónak, máris választ kapunk a kérdésre. Falus (2001) alapján a következő kompetenciákkal szükséges rendelkeznie az oktatóknak és a tanároknak egyaránt: szakmai tudással (tárgyi ismeretekkel), az oktatói, előadói képességekkel (gyakorlati készségekkel). A tanári mesterség fejlesztése pedig mind a tanár, egyetemi oktató, a diákok és hallgatók érdeke is [3]. A felsőoktatásban megvalósuló pedagógiai gyakorlatra két tényező hat: az oktató pedagógiai felkészültsége és a képzésben résztvevő hallgató alkalmassága. Tanulmányunkban az első tényezővel foglalkozunk inkább: az oktatói pedagógiai készségeivel. „A felsőoktatás-pedagógiával foglalkozók köre minimum akkora, ahányan a felsőoktatásban tanítanak" [4]. A felsőoktatás-pedagógiát, az oktatói felkészültséget illetően a legvitatottabb tény az, hogy sok oktatónak nincs pedagógiai gyakorlata, tanári végzettsége. Felmerül tehát a kérdés, hogy a pedagógiai munka során elegendő-e az adott szakterületen megszerzett kimagasló tudás. A gyakorlatban természetesen találkozunk olyan népszerű és eredményes oktatóval, aki nem tanulta a tanári mesterséget. Van olyan oktató is, aki tudományterületében elismert, neves kutató, azonban pedagógiai munkája gyakran kritika tárgya lehetne [5]. Kérdés továbbá az is, hogy milyennek kell lennie egy jó képzésnek, kurzusnak. Coenraad van Houten (1999) szerint a képzés sikerének kulcsa az élet-és gyakorlatorientáltságában rejlik. „Egy műszaki főiskola dékánja elmesélte, hogy sokszor kellett átadnia diplomát olyan mérnököknek, akik letették a vizsgákat, annak ellenére, hogy meg volt győződve arról, hogy nem igazi mérnökök. Megkérdezve, hogy mit ért 'igazi mérnök' alatt, elmondta, hogy milyen kulturális és szociális felelősségük kellene, hogy legyen azoknak, akik egy tudományos kutatás vagy gyártás élén állnak; de kiképzésük folyamán egyáltalán nem lettek előkészítve arra, hogy ilyen felelősséget vállaljanak. Sokan vezetők lesznek, de sohasem tanulták meg, hogy embertársaikat korszerűen vezessék. Tehát itt is hiányzik az általános emberképzés" [6]. A felsőoktatási képzéseknek két szempontnak kell megfelelnie: a szakképzésnek kell elótérben lennie, majd fontos a gyakorlatorientált képzés is, amivel a 
diplomás hallgató könnyen kiléphet a gyakorlati életbe, a munkaerő-piacra és ez megköveteli a magasrendű emberképzést is, amit Coenraad van Houten is kiemelt.

Az oktató - a pedagógiai professzióval azonosulva - döntéseket hoz, hol tudatosan, hol nem tudatosan teszi azt, de minden esetre mindig elemzi az adott szituációt, a kialakult helyzetet. A döntéseit pedig nemcsak a hallgatók, hanem az oktató maga is értékelheti, önreflexiót gyakorolhat. A reflektív oktató visszatér a tevékenységére, elemzi azt és képes felülbírálni döntéseit, megfigyelni saját viselkedését (ld. 1. ábra). A hallgatói reflexiók is rávilágíthatnak az oktatói hiányosságokra, „ballépésekre”, a hallgatói kérdőív mankót ad az oktatóknak a jövőbeli pedagógiai munkájuk (újra)szervezéséhez.

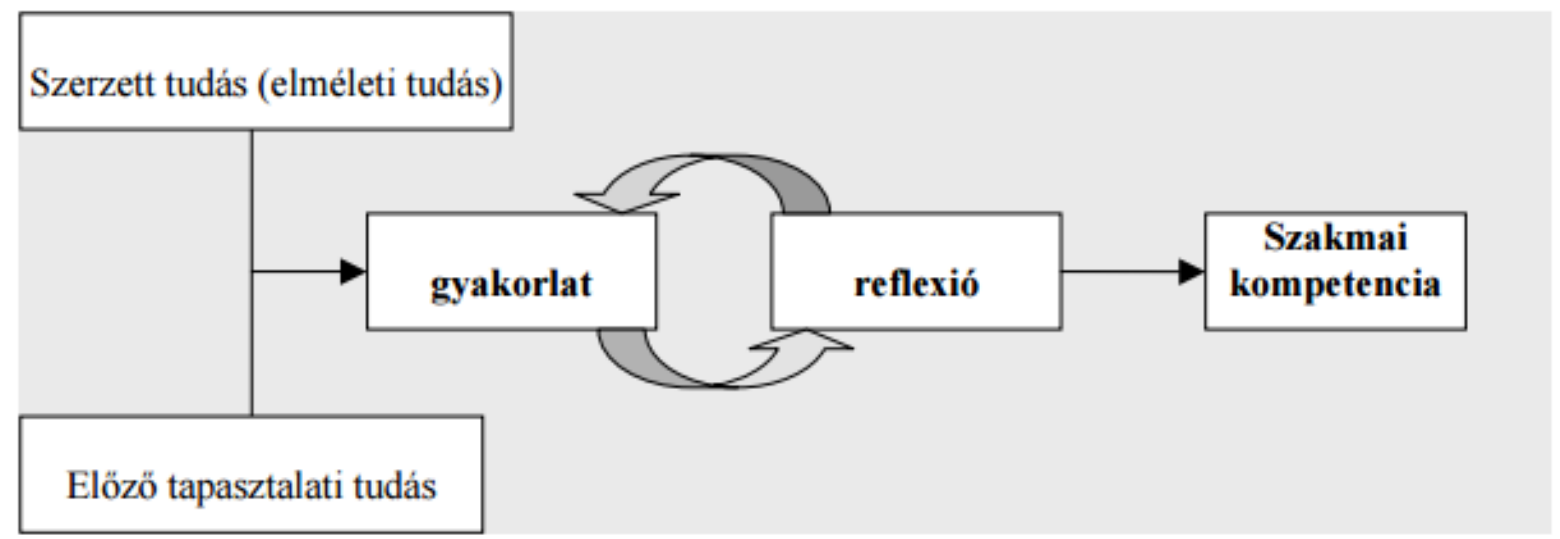

1. ábra: Az oktató szakértelmének fejlődése

(Forrás: [7])

A Debreceni Egyetem Etikai Kódexében az intézmény megfogalmazza az elvárásait az oktatási feladatokat elvégző dolgozóival szemben (is). Eszerint az oktatóknak és az óraadóknak legjobb tudásuk szerint, felkészülten kell átadniuk a tananyagot a hallgatóknak és mindent elkövetniük azért, hogy a lehető leghatékonyabb módon tudják elsajátítani a tananyagot. (Erre szolgál a kurzusokon kiadott jegyzet, segédlet is.) Az oktatói tevékenység fő célja a hallgató szakmai és emberi fejlődésének maximális támogatása [6]. A tanórákat minden esetben köteles megtartani az oktató a megadott helyen és időpontban, indokolt esetben fennáll az óracsere lehetősége. Az oktató kötelessége továbbá, hogy a hallgatókat világosan tájékoztassa az elvárásairól és a hallgatókat felkészítse a számonkérésre és úgy határozza meg a vizsgakövetelményeket, hogy az a kurzus sikeres elvégzésével teljesíthető legyen [8].

Egy prosperáló egyetemen, főiskolán belül fontos, hogy alakuljanak olyan oktatói mühelyek, ahol feldolgozhatóvá válnak a nevelés, tanítás kérdései, ahol önmagukban, szaktudásukban és pedagógiai módszereikben fejlődni tudnak. A DE-GTK-n végzett oktatói véleményezések ezeket a fejlődési célokat szolgálják. 


\section{Az adatbázis, hipotézis}

A tanulmány elkészítéséhez a DE-GTK Kontrolling szakirány kurzusait látogató hallgatók értékelését vizsgáltuk, amit oktatóikról írtak. A kérdőív 19 kérdést tartalmazott és három fóbb kérdéskört érintett, ezek a következők voltak: a tanóra típusa, látogatásának és tartásának gyakorisága és az oktató pedagógiai szempontú értékelése. A kérdőívet összesen 125 hallgató töltötte ki, azok, akik a Kontrolling szakirány kurzusain részt vettek. A kérdőív nem tartalmazott nyitott kérdéseket, a számszerűsíthető válaszokat SPSS programmal elemeztük.

A szakirodalom és a Debreceni Egyetem Etikai Kódexe alapján az alábbi hipotéziseket fogalmaztuk meg:

1. Hipotézis: A Gazdaságtudományi Kar tanárai törekednek arra, hogy megfeleljenek a Debreceni Egyetem Etikai kódexében foglaltaknak, ezek alapján feltételezzük, hogy legjobb tudásuk szerint felkészülten adják át ismereteiket és szakértelmüket a diákok számára.

2. Hipotézis: A tanárok megteremtik a lehetősége arra, hogy a hallgatók a leghatékonyabb módon legyenek képesek elsajátítani a tananyagot.

3. Hipotézis: A tanárok a tanagyaghoz igazítják a vizsgakövetelményeket és igyekeznek oldott légkört biztosítani. Ehhez pozitívan járul hozzá a jó oktató-hallgatói viszony.

\section{A kutatás eredményei}

A hallgatók 40,2\%-ának előadások, 59,8\%-ának gyakorlatok, szemináriumok vagy speciális kollégiumok keretein belül nyílt lehetősége az oktatóval találkozni. Az 2. ábrán kitúnik mind az oktatók, mind a hallgatók elkötelezettsége, hisz igen magas mind a megtartott órák, mind az órákat látogatók aránya. A hallgatók több mint háromnegyede (79,3\%) látogatta az órákat, ugyanakkor az oktató az órák 97,6\%-át megtartotta.

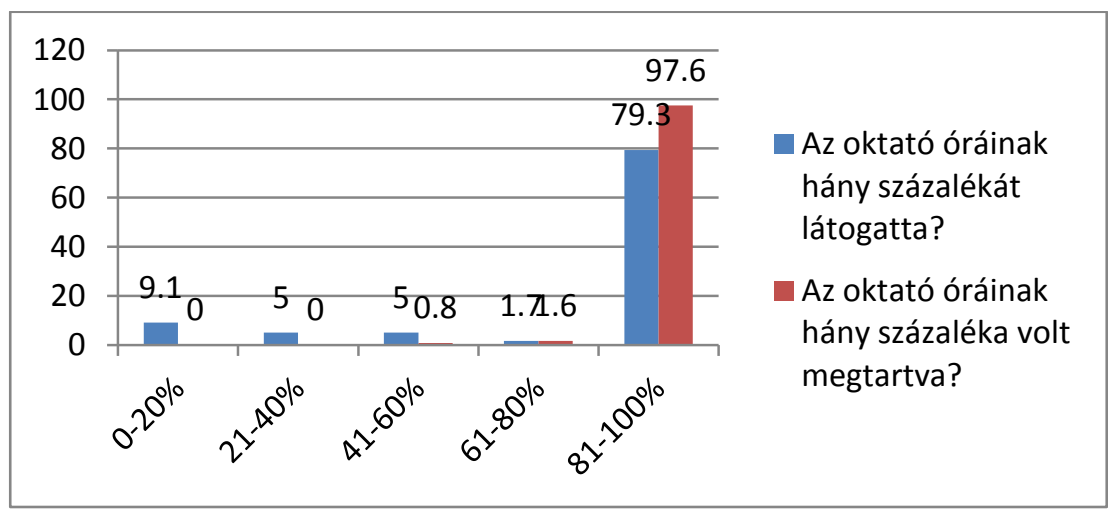

2. ábra: A megtartott órák, és az órákat látogatók aránya (N=125)

(Forrás: Saját szerkesztés) 
A következőkben a hallgatóknak az oktató pedagógia munkáját kellett értékelniük, egy 1-5-ig terjedő Likert skála segítségével. A hallgatók számára felsoroltunk 15 itemet, melyek a következő négy dimenziót foglalják magukba:

1. az oktató szakmai tudása, felkészültsége és oktatói képessége,

2. a hallgatók tananyag elsajátításának módjai, lehetőségei,

3. tanár-diák kapcsolat,

4. tananyag és követelmény összhangja, vizsgaszituáció.

Az első dimenzió az oktató felkészültségét, tudását és oktatói képességét vizsgálja, a következő változók segítségével: az oktató beszédének érthetősége, az oktató felkészültsége, az átadott ismeretek érthetősége, figyelemfelkeltő és érdekessége. A 3. ábrán látható, hogy a hallgatók legnagyobb arányban az oktató beszédének érthetőségét preferálták. Az oktató felkészültségét, az átadott ismeretek világosságát meglehetősen jónak értékelik. A hallgatók azonban kevésbé tartották érdekesnek és figyelemfelkeltőnek a látogatott órákat.

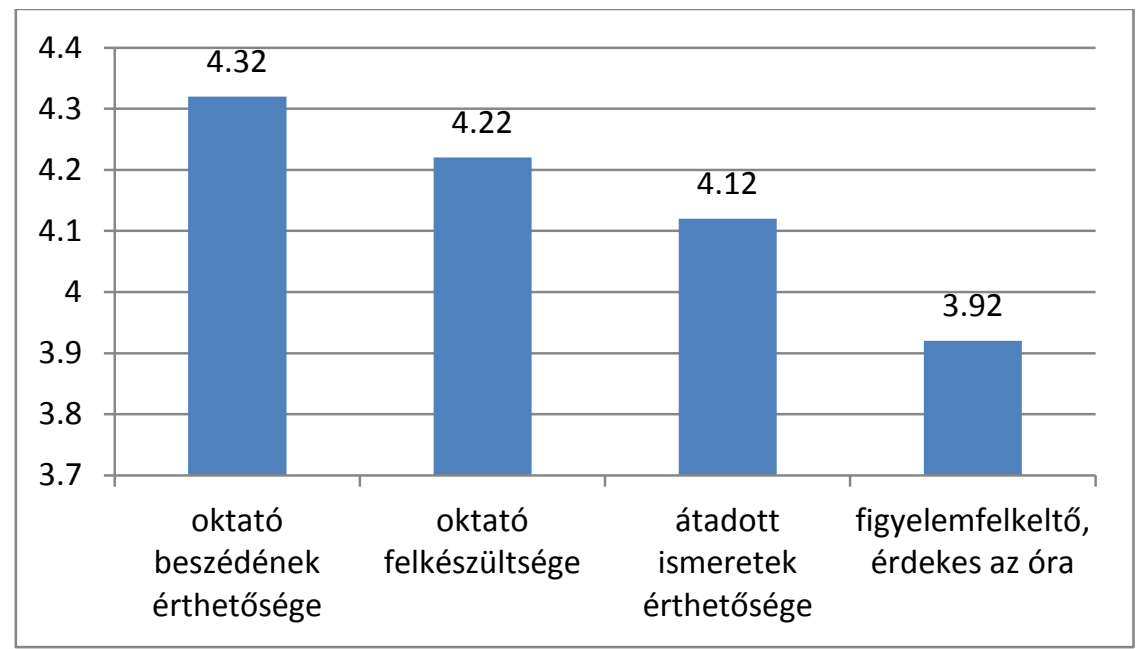

3. ábra: Az oktató szakmai tudásának, felkészültségének és oktatói képességének vizsgálata ( $N=118, N=123, N=121$, $N=118)$

(Forrás: Saját szerkesztés)

A második dimenzió azt járja körül, hogy vajon az oktató biztosítja-e a megfelelő és elegendő segédletet, jegyzetet ahhoz, a diákok képesek legyenek elsajátítani a tananyagot. A 4. ábrán látható, hogy a diákok jól tudnak jegyzetelni az órákon. A tananyag elsajátítását elsősorban nem a tanórán elhangzottak segítik, azonban az oktató által nyújtott segédletek és jegyeztek annál inkább hozzájárulnak a tananyag sikeres megértéséhez. A 4. ábrán az is látható, hogy jobban preferálják a diákok azokat a jegyzeteket, melyeket a tanár biztosít, mint azokat, amelyeket maguk készítenek az órákon. 


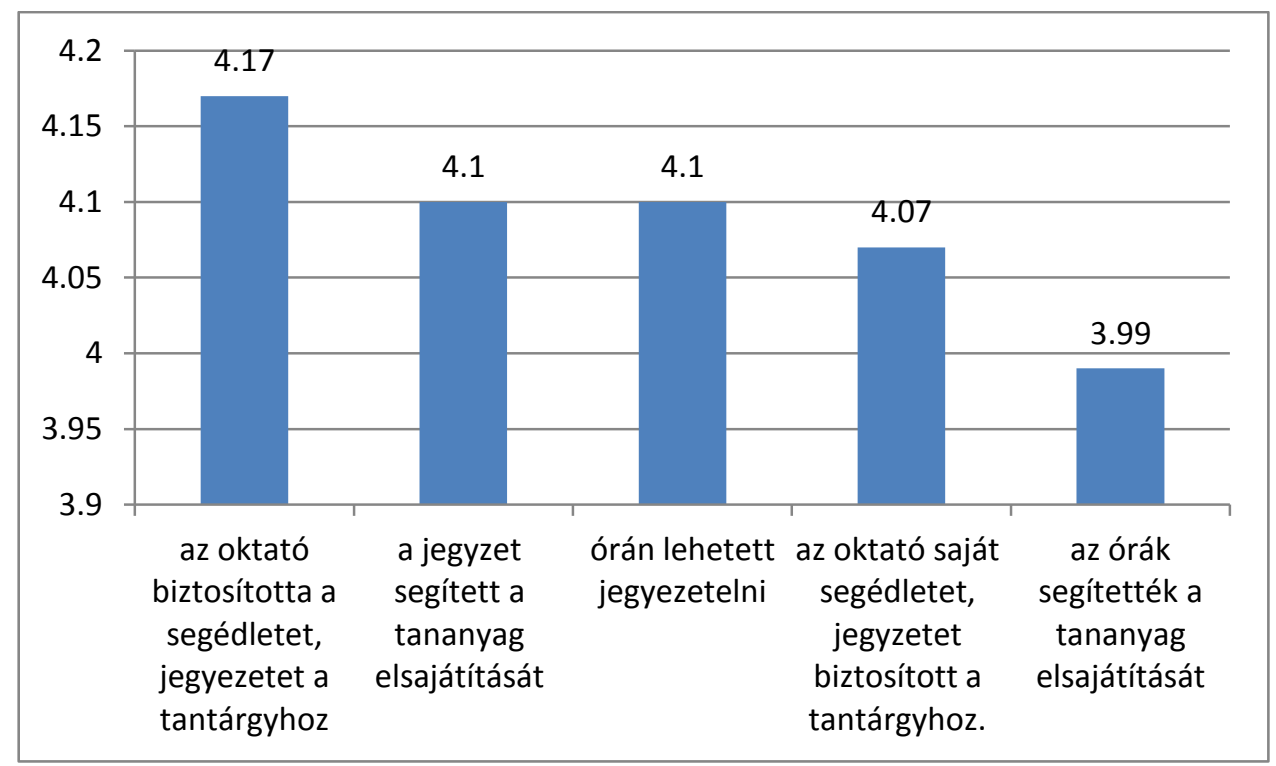

4 ábra: A hallgatók tananyag elsajátításának módjai, lehetőségei ( $N=121, N=117, N=121, N=118, N=122)$

(Forrás: Saját szerkesztés)

A harmadik dimenzió a tanár diák kapcsolatot vizsgálja, egyrészt, hogy mennyire pozitív a tanár hozzáállása a diákhoz, másrészt pedig, hogy az oktató mennyire képes rugalmasan kezelni a hallgató kéréseit. Az 5. ábrán látható, hogy a hallgatók válaszai alapján a tanárok pozitívan állnak a diákokhoz és igyekeznek eleget tenni a hallgatói kéréseknek.

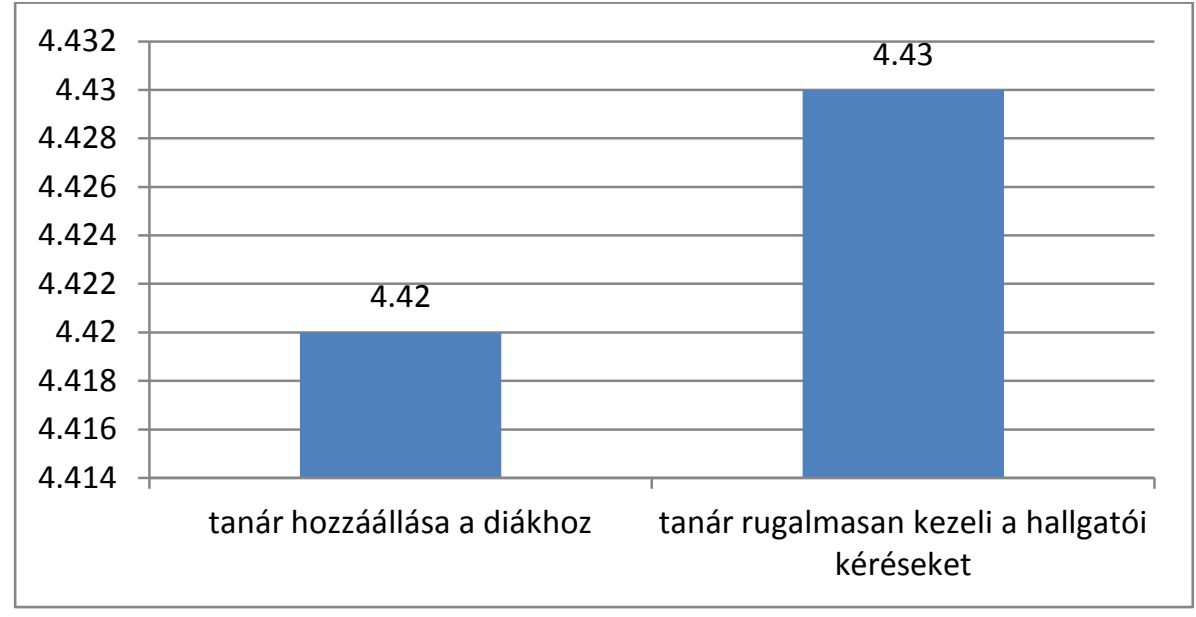

5. ábra: A tanár-diák kapcsolat ( $N=118, N=119)$

(Forrás: Saját szerkesztés)

A negyedik dimenzió egyrészt a tananyag és követelmény közötti összhangot, másrész szóbeli és írásbeli vizsga jellemzőit vizsgálja. A 6. ábrán látható, hogy hallgatók igen pozitívan vélekedtek arról, hogy a vizsgák során a vizsgakérdések összhangban állnak a tananyaggal $(4,62)$, illetve össszhangban áll a számonkérés és a kapott jegy $(4,61)$. A hallgatók a szóbeli vizsga légkörét is kedvezőnek ítélték, hisz az 1-től 5-ig terjedő skálán 4,61 pontot kapott. Ennél kevésbé tarottták az írásbeli vizsgát 
lényegretörőnek $(4,56)$, de még ez is jónak mondható.Legkevésbé kiválónak a hallgatók a vizsgák során, a tudásuk felmérésére való törekvést tartották. $(4,47)$.

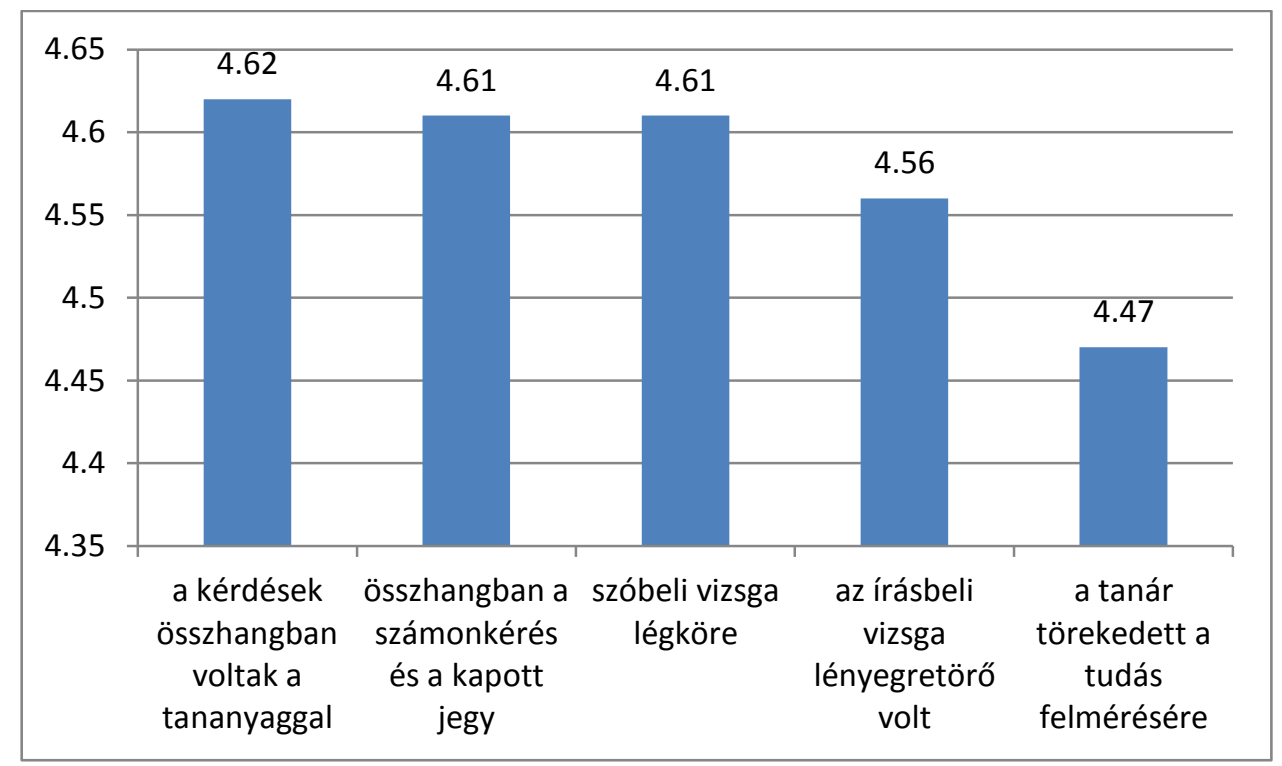

6. ábra: A tananyag és a követelmény összhangja, vizsgaszituáció (( $N=117, N=120, N=110, N=117, N=118)$

(Forrás: Saját szerkesztés)

\section{Összegzés}

A szakirány kurzusainak értékelése fontos eleme az oktatók pedagógiai készségeinek fejlesztésének, kiindulópontot adhat a jövőbeli oktatói munka megszervezéséhez, átalakításához. Összességében látható, hogy a Debreceni Egyetem Gazdaságtudományi Karán működő Kontrolling szakirány kurzusait látogató hallgatók elégedettséggel számoltak be az oktatók munkájáról. Hipotéziseink beigazolódni látszanak, miszerint a tanárok munkája megfelel az Etikai Kódexben leírtaknak, hisz felkészülten, érthetően, érdekesen és figyelemfelkeltően adják át ismereteiket a hallgatóknak. A tanárok megfelelő hangsúlyt fektetnek arra, hogy megteremtsék a lehetőséget a diákok számára (jegyzetekkel, segédanyagokkal), hogy minél hatékonyabban legyenek képesek elsajátítani a tananyagot. A hatékonyság tekintetében a tananyag elsajátítását jobban segítette a tanárok által biztosított jegyzet vagy segédanyag, mint a hallgatók saját készítésű jegyzetei. A tanárok igyekeznek egyrészt a tananyaghoz igazítani a vizsgakövetelményeket mind az írásbeli, mind a szóbeli vizsga esetén, másrészt a hallgatók tényleges tudását felmérni. Az adatok azt mutatják, hogy összhangban áll a számonkérés és a kapott jegy, és a vizsgafeladatok is lényegretöőek. A vizsgákon a jó oktatóihallgatói viszonynak köszönhetően oldott a légkör.

\section{Hivatkozások}

[1] Z Báthory (1985): Tanítás és tanulás. Budapest: Tankönyvkiadó. 
[2] J Kocsis Bognárné (2012): A pedagógiai értékelés tervezésének egy lehetséges útja a felsőoktatásban. Új Pedagógiai Szemle, 9. évf. 10. sz. 39-49. o. [3] F. H. Knight, Risk, Uncertainty and Profit. Dover Publications, Inc., Mineola, New York, 2006.

[3] I. Falus (2001): Pedagógus mesterség - pedagógiai tudás. Iskolakultúra, 2. sz. 21-28. o.

[4] G Halasz (2013): A felsőoktatás-pedagógia trendjei. Felsőoktatási műhely.

[5] Gy Drótos - G Kováts (szerk.) (2009): Felsőoktatás-management. Aula Kiadó, Budapest, 160-162. o.

[6] C HOUTEN (1999): Erwachsenenbildung als Willenserweckung Freies Geistesleben. London: Temple Lodge Publishing

[7] M Kimmel (2006): A tanári reflexió korlátai. Pedagógusképzés, 3-4. sz. 36. o.

[8] Debreceni Egyetem Kódexe. Megtekinthetö: https://www3.unideb.hu/portal/sites/default/files/szabalyzatok/Etikai_Kodex_160211.pd $\mathrm{f}$ 